\title{
GEOSYNTHETICS, A VERSETILE SOLUTION TO CHALLENGES IN GEOTECHNICAL ENGINEERING
}

\author{
R. H. Jadvani ${ }^{1}$, K. S. Gandhi ${ }^{2}$ \\ ${ }^{1,2}$ Assistant Professor, Civil Engineering Department, Sarvajanik College of Engineering and Technology, \\ Surat-395001, Gujarat, India, ratna.jadwani@scet.ac.in, khushbu.berawala@scet.ac.in
}

\begin{abstract}
This paper focuses on the available state of knowledge in the field of soil improvement particularly by the use of geosynthetics. Geosynthetics have found an important place in geotechnical engineering problems i.e. foundation on soft soils, land slide control, sub grade stabilization, reinforced embankments over soft soils, erosion control (turf reinforcement, under rip rap), surface drainage etc. This paper gives an overview of geosynthetics from its historical development to latest trends in it.
\end{abstract}

Index Terms: Geosynthetics,

\section{INTRODUCTION}

In Civil engineering practice the load from super structure is to be transferred to a soil layer through footing that is capable to withstand this load with adequate factor of safety under tolerable settlement. There are various sub soils such as soft marine clay, new born sandy area by dunes, reclaimed land where in adequately strong layer may not be available at shallow depth. It becomes therefore necessary to transfer the load at a great depth where strong bearing layer is available by adopting pile foundation, pier foundation, cassion foundation. This method of insertion of structural component into the soil medium is highly expensive and installation causes many practical complications. If this soft soil medium is not too deep, stone columns, lime piles and other stabilization techniques such as grouting, vibro-flotation, compaction piles are also in common. These methods are also proved to be uneconomical, time consuming and laborious.

With the investigation made on use of geosynthetics for the purpose of improvement of sub-soil properties, soil reinforcement by geotextile, geomembrane, geogrids and geocomposits has gained momentum. It is claimed that use of geosynthetics as soil reinforcement has many advantages over conventional soil improvement method. In that it is less expensive, easy to construct and highly effective in improving the soil properties

Due to reasons stated above, research work on reinforced soil in different disciplines of geotechnical construction has been under taken all over the world. (Dembiki et al (1988)[4], Haroon et al (1990)[7], Ingar (1990)[8]. In our country, 9 excellent research work has been under taken since last four decades (Murthy and Shridharan 1988 [12], Verma and Char 1986 [33]).

\section{HISTORICAL DEVELOPMENT}

Science the beginning of civilization man has attempted to use soil with other materials to enable it for being used for his requirements. Typical uses include use of branches of trees etc to support track over marshy areas,to build large structures, temples such as ziggurauts of Babyloniya, to build hutments with woven mats of reeds etc. These have also been used in parts of Great Wall of China.

Geotextile material was first used in road construction in South California in early 1930's. The first woven synthetic fabric for erosion control was used in 1950's in Florida by Barret. In 1960's geotextiles were extensively used for erosion control both in Europe as well as U.S.A..Later in 1969, Giround used non- vovan fabrics as a filter in the upstream face of an earthen dam. In 1971, Wager initiated use of woven fabrics as reinforcement for embankments constructed on very soft foundation soils. Today the use of geosynthetics is more common for wide range of civil engineering applications.

\section{CLASSIFICATION OF GEOSYNTHETICS}

1. Geotextiles 2. Geomembranes 3. Geogrids

4. Geocomposits 5. Geofoams 6. Geocells 7. Geotubes Etc....

Geosynthetics originally are called by different name such as filter fabrics, plastic filter cloth, engineering fabric, civil engineering fabric geofabric and geotechnical fabric.

The name geotextile (though related to woven and kitted and non-woven fabrics) is currently being applied to many materials which may be best treated as geotextile related materials which include webs, mats, nets grids etc. Hence, the term which is proposed in 1983 by Prof. Robert M. Koerner, Director of geosynthetics Research Institute and now being 
increasingly used is "Geosynthetics" which encompasses Geotextiles, Geomembranes, Geogrids, Geocomposits. Geotextile are indeed textiles in the traditional sense, but they consist of synthetic fibers rather than natural ones such as cotton, wool, or silk. Thus bio degradation and subsequent short lifetime is not a problem. These synthetic fibers are made into flexible, porous fabrics by standard weaving machinery or are matted together in a random non woven manner.
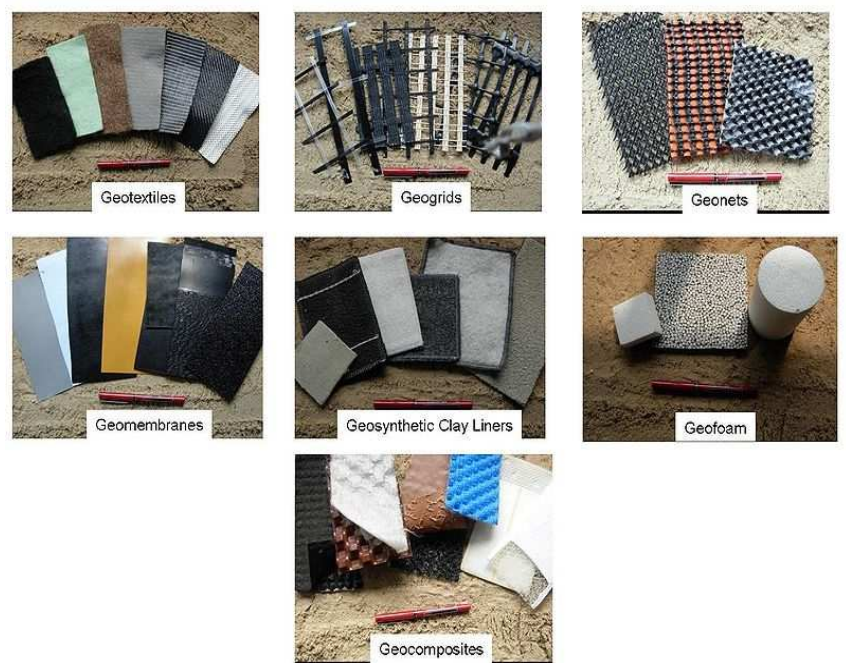

Fig-1: Types of geosynthetic materials

A Geomembrane is defined as a continuous membrane type liner and barrier composed of asphaltic, polymeric or combination thereof materials with sufficiently low permeability so as to control fluid migration in a geotechnical engineering related man-made project structure or system.
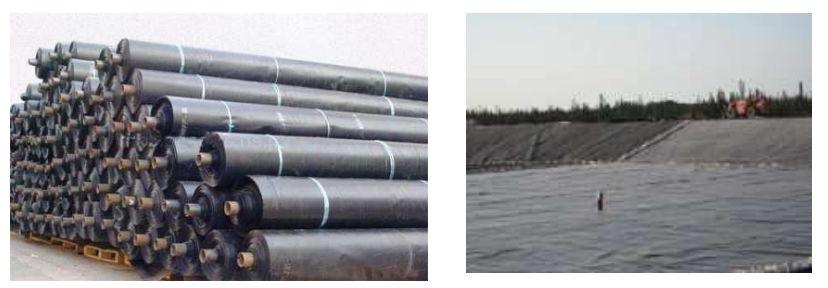

Fig-2: Geomemranes and its application

The term geosynthetics is a general term which includes geotextiles, geomembranes, geogrids nets, geocomposits and all other similar material used by civil engineers to improve or modify soli behavior. The major functions of geocomposits are separation, reinforcement, filtration, drainage, and containment.

A geogrid is any synthetic planar structures formed by a regular network of tensile elements with apertures of sufficient size to allow inter locking with surrounding soil, rock or any geotechnical material. Geogrids are characterized by high dimensional stability and high tensile modulus at very low elongation.

Geonets, called geospacers by some, constitute another specialized segment within the geosynthetics area. They are made by a continuous pushing out of parallel sets of polymeric ribs at acute angles to one another. There are two types of geonets, biplanar and triplanar. Their purpose is completely within the drainage area where they are used to convey liquids of all types.

Geofoam is a product created by a polymeric expansion process resulting in "foam" consisting of many closed, but gasfilled, cells. The primary function of geofoam is separation.

When geogrids/geotextile/geomembranes are combined with woven or non-woven geotextiles or geogrids for specie applications like drainage, erosion control, bank protection, they are designated as geocomposite.

Geocells are also known as Cellular Confinement Systems, are three-dimensional honeycombed cellular structures that form a confinement system when infilled with compacted soil.. Traditionally used in slope protection and earth retention applications, geocells made from advanced polymers are being increasingly adopted for long-term road and rail load support.

Geotube are huge tube of geosynthetic material used, dewatering sewage sludge, erosion control and for making marine structures like brake water etc.

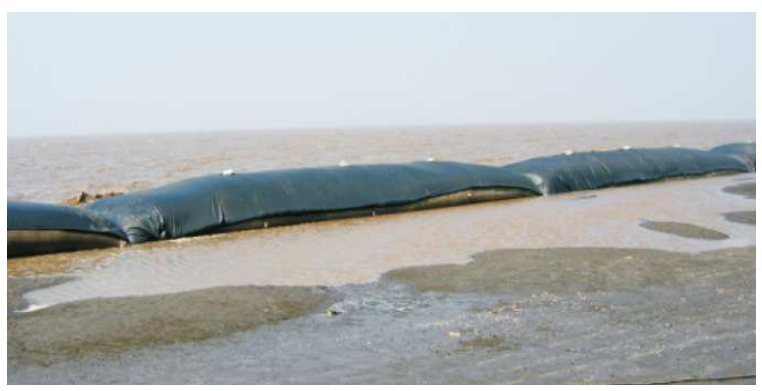

Fig-3. Geotubes

Parab S. R., Chodankar D. S., Shirgaunkar R. M., Fernandes M. , Parab A. B., Aldonkar S. S., Savoikar P. P. carried out the study in Goa to check the effectiveness of geotubes for erosion control of the beaches.[15]

Das N. K., Mandal J. N., Mandal T. carried out an experimental and FEM on geotextile geotube . A hanging bag test was carried out for dewatering of slurry sludge at Powai lake, Mumbai, India. The hanging bag and the working plateform were fabricated at IIT Bombay. The properties of 
soil and geotextile geotube were reported. Based on the hanging bag test, the flow rate of slurry material and water level are recorded at specific time period. The FEM analysis was done using PLAXIS version 8.2. The test result showed that proper selection of geotube and filling material has significant importance.[3]

\section{BASIC FUNCTIONS OF GEOSYNTHETICS}

Fluid transmission: It has conventionally being termed as drainage function. A geotextile can collect and convey fluid along its own plans.

Table- 1: Primary Function for Each Type of Geosynthetic

\begin{tabular}{|c|c|c|c|c|c|c|}
\hline Type & $\begin{array}{l}\text { Sep } \\
\text { arati } \\
\text { on }\end{array}$ & $\begin{array}{l}\text { Reinf } \\
\text { orce } \\
\text { ment }\end{array}$ & $\begin{array}{l}\text { Filt } \\
\text { erat } \\
\text { ion }\end{array}$ & $\begin{array}{l}\text { Drai } \\
\text { nage }\end{array}$ & $\begin{array}{l}\text { Conta } \\
\text { inmen } \\
\mathrm{t}\end{array}$ & $\begin{array}{l}\text { Erosio } \\
\mathrm{n} \\
\text { Contro } \\
1\end{array}$ \\
\hline $\begin{array}{l}\text { Geotext } \\
\text { iles }\end{array}$ & $\sqrt{ }$ & $\sqrt{ }$ & $\sqrt{ }$ & $\sqrt{ }$ & & \\
\hline $\begin{array}{l}\text { Geome } \\
\text { mbranes }\end{array}$ & & & & & $\sqrt{ }$ & \\
\hline $\begin{array}{l}\text { Geogrid } \\
\mathrm{s}\end{array}$ & & $\sqrt{ }$ & & & & \\
\hline $\begin{array}{l}\text { Geocom } \\
\text { posits }\end{array}$ & $\sqrt{ }$ & $\sqrt{ }$ & $\sqrt{ }$ & $\sqrt{ }$ & $\sqrt{ }$ & $\sqrt{ }$ \\
\hline $\begin{array}{l}\text { Geofoa } \\
\text { ms }\end{array}$ & $\sqrt{ }$ & & & & & \\
\hline $\begin{array}{l}\text { Geocell } \\
\mathrm{s}\end{array}$ & $\sqrt{ }$ & $\sqrt{ }$ & & & & \\
\hline $\begin{array}{l}\text { Geotube } \\
\mathrm{s}\end{array}$ & $\sqrt{ }$ & & & & & $\sqrt{ }$ \\
\hline
\end{tabular}

\section{EXPERIMENTAL EVALUATION FOR A} REINFORCED SOIL:

The improvement in the properties of soil using geotextiles is a developing field. Many people have worked and are still working in this field. Determination of improvement in strength of soil reinforced by geotextile or random fiber has been undertaken by many investigators.

Freitag (1986) conducted a study to compare the unconfined compression strength of plain and reinforced specimens compacted over a wide range of water content. The soil was mixed with water and then the desired amount of fiber was added and mixed into the soil. The fiber content was $1 \%$ by volume. Duplicate specimens were prepared and tested for each of the test conditions. The unconfirmed compression tests were performed immediately after compaction. It was found from the test results that the strength of reinforced soil compacted near and wet of O. M. C. was greater than for plain soil at the same water content. Also at higher water contents, the strength of the plain soil diminished more rapidly compared to that of the reinforced soil. [6]

C. Subbarao and J. P. Prasad have carried out triaxial tests on sand reinforced with poly-propylene fabric to study the strength and deformation characteristics of the composite material. They also studied the effect of varying area of reinforcement, number of layers of reinforcement and confining pressure during triaxial tests. By using fabrics as reinforcing material in sand, there is an increase in $\phi$ or $\mathrm{C}$ or both. The results of triaxial shear test showed that fabric reinforcement is a viable alternative to metallic reinforcement.[32]

N. Narayan Swamy, Setty and Rao investigated the strength behavior lateritic soil reinforced with synthetic fibers. They observed that by using fiber reinforcement, although there is some reduction in the angle of friction, there is a substantial increase in the value of cohesion. The reduction in $\phi$ may be due to smoothness of fibres.[26]

They found that B. C. R. values are improved by $44 \%, 117 \%$ and $122 \%$ of that of the unreinforced soil with $1 \%, 2 \%$ and $3 \%$ fiber respectively, in the case of samples tested at O. M. C. The tensile strength was also found to be improved by a considerable amount.

Mandal and Divshikar suggested test method for determining creep potential of jute geotextile. Jute geotextile were used in dry and wet conditions. Static load was applied and creep potential was determined. From this test only a qualitative evaluation of geotextile can be made. This test is sufficient for use in selecting fabric for design purpose in installations where fabric creep could have determinantal effects on overall project initial and time depend performance.

They recommended that only fabrics with nil or low creep potential should be used in projects where fabric creep could be determental to project performance assuming that such fabric satisfy all other requirements. The reinforced soil was found to absorb more energy. [10]

Singh and Slavoshnia (1988) carried out an experimental study to evaluate the effectiveness of using a synthetic geotextiles singly in layers and in a system alternating with anchors called the 'combined system' (Singh and Finlay 1986) for soil reinforcement for use in embankment situation. A coal mining waste soil, finer than $20 \mathrm{~mm}$ size was used a the fill material. The end results of the tests presented showed that a geotextile can be used more effectively for soil reinforcement in a 'combined' rather than in a 'separate' system. [28]

Jalota, Shrivastava and Tripathi (1988) made a study of strength deformation characteristics of geotextile reinforced clayey soil by varying size of sample, number of reinforcing 
layer etc. For this, a series of unconfined compression test and undrained triaxial test at various confining pressures have been conducted. It was observed from the results of unconfined compression test that the effect of reinforcement on stress strain relationship is more prominent when three layers of fabric are introduced at equal spacing. The degree of improvement due to presence of reinforcement is more at higher strain rate and in large diameter sample. The value of cohesion and $\phi$ in triaxial test increases with the number of reinforcement layers.[9]

Rao, Kachhawath and Gupta (1987) carried out three series of strain controlled triaxial shear test on fine grained uniform sand, using two varieties of geotextile for verifying the validity of model developed by Housemann (1976) for metallic reinforcement. The results of this tests indicate the applicability of Housemann's model with a difference that no geotextile rupture occurred even at high confining pressure. It was also noted that the influence of geotextile appears to decrease with an increases in confining pressure.[20]

Raghvendra and Krishnaswami (1990) conducted undrained triaxial test on kaoline samples reinforced by geotextile. In order to study strength - deformation behavior of cohesive soil, the samples were prepared at two different moisture content, one on dry side of optimum and other on we side of optimum. It was noted that higher strain rate results in higher strength particularly in saturated sample. However maximum improvement in strength ratio (strength of reinforced sample strength of plain soil sample) is independent of strain rate.[18]

Donald and Talal Al-Refeal (1985) studied the behavior of fabric versus filter - reinforced sand. They conducted triaxial compression to compare the stress - strain response of sand reinforced with continuous oriented fabric layers as opposed to randomly distributed, discrete fibers. The influence of various test parameters such as amount of reinforcement, confining stress and inclusion modulus and surface friction were also investigated. Test results showed that both types of reinforcement improved strength, increased the axial strain at failure, and in most cases reduced post-peak loss of strength. At very low strains $(<1 \%)$ fabrics inclusion resulted in a loss of compressive stiffness. This effect was not observed in the case of fiber reinforcement. The existence of a critical confining stress was common to both systems. Failure envelops for reinforced sand paralleled the unreinforced envelope above this stress. Strength increases was generally proportional to the amount of reinforced, i.e. the number of fabric layers or weight fraction of fibers up to some limiting content. Thereafter, the strength increases approached on asymptotic upper limit. Fiber-reinforced samples failed along a classic planar shear plane, where as fabric reinforced sand failed by building between layers.

Geotextiles as Filters and Drains:
Geotextiles are synthetic permeable sheets which can be used in various Civil Engineering projects for the purpose of drainage and filtration. They are highly permeable and can be effectively used as drainage layers when placed in soils of low permeability. They gather water from the surrounding soil and convey it towards outside the structure. They also prevent the built up of excess pore water pressure in the soil. They also perform the function of filtration. Uniformly graded filters combined with geotextiles are now widely used due to their ease of handling and construction, economy and better performance. The primary function of filters is to prevent the migration of soil fines and at the same time to allow free flow of seeping water without building up of excessive hydraulic pressure. [5]

Ramaswami, Senathipathy and Sathiavent (1989) conducted laboratory studies on the use of geotextiles as filters. They compared the performances of graded filters and uniform filters protected with geotextiles. It was observed that the performance of geotextile filter system was found to be better than that of graded filters and both woven and non-woven geotextiles can be advantageously used in filter using geogrids.[22]

Saxena and Sarkar (1988) carried out a study on slope erosion protection using extruded polymer geogrids. In their study, they included soil erosion control measures against surface runoff, primarily as watershed due to rainfall and flooding of natural and manmade slopes like embankments, dams etc. When soil is reinforced by geogrids, geogrid provides root anchor and a high tensile net flexible structure is formed which adopts to ground contour lika a skin and stops local slip failures against local passive movement of soil. Since geogrids don't bio-degrade, its long life assures fit and forget applications.[25]

Patel N. M. (1988) presented findings of systematically conducted laboratory studies by placing of geotextile at some depth in a virgin weak soil deposit and with good variety fractural sand above the geotextile. He also reported results of tests conducted without geotextile and this comparison gives the contribution of geotextiles by its reinforcing action. He also indicated the optimum depth of placement of the geotextile which can give best improvement in the performance of the system. Thus, the study gives insight of the mechanism responsible for this method of ground improvement.[16]

\section{EXPANSIVE SOIL REINFORCED WITH GEOSYNTHETICS}

In India, especially in the black cotton soil regions, the swelling of sub grade soils constitute one of the challenging problems for field engineers. In case of road and building foundations on expansive soil areas, the phenomenon of heaving and shrinking is a matter of common occurrence. The 
swelling pressure is not constant for a given type of soil. It is influenced by various factors such as density, initial and final moisture content, confinement, strength, compressibility, gradation, index properties etc.

Murty, Chandra and Bhagwan studied the influence of geotextiles on swelling and swelling pressures in soft clays. Most of the tests for above purpose were conducted using odeometer or constant volume moulds. The soil at different layers was embedded with geotextile fabrics and the swelling characteristics of the composite system were studied. From the test conducted of black cotton soil, it was concluded that there is not much variation in the amount of swelling in case of soil and soil-geotextile system when geotextiles layers are not provided with vertical drainage path since there is no provision for free water to drain out.

They found that swelling is reduced by 30 to 60 percent when the drainage path is provided. It was also found that nonwoven geotextiles are more effective compared to woven and needle fleeced fabrics. [11]

Natarajan, Murthy and Bhagwan (1987) conducted the laboratory tests on the cotton soil - geotextile system introducing the geotextile samples at different spacing in the triaxial compression and in the unconfined test to investigate the possible effect of fabric reinforcement on the stress strain behavior of the black cotton soil. [14]

Dr. A. V. Shroff carried out the study on Geotextile reinforced road on Expansive clay in Gujarat at command area of UkaiKakrapar in south Gujarat. It was taken up jointly by GERI, CRRI, MSU, MERI and World Bank. Imported woven nonwoven and needle fleeced geotextiles were used. Formation width of road was $10 \mathrm{~m}$ and width of Geotextile roll was 4.5 $\mathrm{m}$, and therefore, it was laid in three passes with an overlap of $25 \mathrm{~cm} .10 \mathrm{~cm}$ layer of sand over Geotextile was laid to act as cushion while compacting the sub-base before laying hand broken metal of $63 \mathrm{~mm}-40 \mathrm{~mm}$ size and compacted by 4 ton roller. Compaction was possible after sand below aggregate is made wet. After 2nd layer of aggregate 8 ton roller was used and finally finished surface of $20 \mathrm{~mm}$ semi dense carpet of WBM. As far as distress is concerned the performance of nonwoven was better. [27]

Daigavane P. B., Dawande G. M., Gulhane S. W., Chaudhari N. D. carried out a study to investigate technique for improving the degree of consolidation and drainage condition using cylindrical prefabricated vertical geofoam drains in black cotton soil wich dissipate the excess porewater pressure. Constant volume methods were applied using square footing and load-settelment relationship was plotted. The result showed a significant improvement in the settelemement rate and ultimately the degree of consolidation by using prefabricated vertical geofoam drains as compared to without using prefabricated vertical geofoam drains. This was found to be one of the effective and innovative techniques to improve black cotton soils. When the geotextiles have been used as reinforcing material in a soil-fabric system, the basic properties of the geotextiles to be considered are tensile strength, elongation, soil fabric friction mobilized by the system. Three types of geotextiles namely woven, non-woven and needle fleeced were used. It was concluded from the test results that geotextile made of polyamide and polymers are particularly suited for use as reinforcing elements is soft soils. Study also included that a single layer reinforcement properly placed to intercept the failure plane could be for more effective than two or three such fabric layers introduced random at other levels. [2]

\section{SOIL REINFORCEMENT INTERACTION}

Reinforced earth structures are gaining popularity and in recent past have replaced some of the conventional earth structure.

In reinforced soil system, the lateral flow of soil under overburden pressure is suppressed by soil-reinforcement frictional interaction which is caused by relative movement. The soil-reinforcement frictional interaction is due to both bonding and bearing.

Two types of relative movement can be distinguished which are responsible for the soil-reinforcement interaction are pullout of reinforcement from stationary soil mass and flow of soil mass over stationary reinforcement.

Murthy, Sridharan, Bindumadhava and Herkal (1988)conducted pullout test in the specially designed pullout box. The test was done by varying spacing and number of lateral elements of the grid and diameter of the lateral element. It was found that the number of transverse elements and their spacing substantially influenced the pullout results of the reinforcement. They suggested a method to overcome the boundary effect which affected the pullout results.[12]

Rao, Kate and Katti (1990) developed a pullout test apparatus to measure pullout resistance of geogrids in the soil system. The test was conducted on NETLON CE 131 goegrids in interaction with Mubra Sand. It was found that the resulting behavior depends on the embedment length. [19]

Rao and Pandey (1988) conducted pullout test and direct shear test for the evaluation of soil geotextile friction. They placed a strip of geotextile between the two having of direct shear box filled with soil and was pulled out. The force required to pullout the geotextile was than obtained. Pullout resistance at different normal stresses was obtained and both and bond stress versus normal stress relationship was developed. It was found that the value of friction decreases with increases in normal stress and length of embedment which was in 
agreement with the studies conducted by (Alims et.al 1977) and (Bacot et.al 1978). [21]

\section{APPLICATION OF GEOSYNTHETICS IN ROADS AND RAILWAYS CONSTRUCTION}

Geotextile is now universally adopted in many geotechnical engineering woks. They have been extensively used for the construction of roads. Geotextile placed between the aggregate layer and the subgrade performs several functions like separation, filtration, drainage and reinforcement.

Nagaraju and Mhaiskar (1990) conducted laboratory C.B.R. test and field plate load test on reinforced and unreinforced soil for the design of paved roads for C. B. R. test, bentonite cement slurry is used as subgrade and aggregate between 9 $\mathrm{mm}$ to $12 \mathrm{~mm}$ were used as reinforcing material. It was recommended that the system of soil filled geotextile tube below geotextile layer would be more efficient in reducing subgrade stresses compared to conventional aggregate layer or aggregates on geotextile of comparable thickness. [13]

Setty and Rao (1987) conducted C. B. R. and other test on reinforced lateral soil in order to study the improvement in $\mathrm{C}$. B. R. value, shear strength value and tensile strength to estimate the improvement in road pavement design. It was noticed that incorporation of fibers improves C. B. R. value by $19.31 \%$ with addition of $3 \%$ fiber by weight. Where as tensile strength of soil improves by more than $100 \%$. It was also found that cohesion of the soil improved by 6 times where $s$ angle of internal friction of reinforced soil drops. [26]

Sivapragasam C. , Vanitha S. , Arun V. M. and Sutharsanam S. (2010) carried out the study on synthetic geotextile for road pavements. The project was developed for Virudhu nagar district which was around $20 \mathrm{kms}$ in length. The subgrade was to be stable, unyielding, properly drain and free from volume changes due to variation in moisture. Otherwise it would lead to pavement failure. Normally pavement fails due to the reasons such as structural, functional or material failure, or combination of this. But in the study area it was observed that the pavement failure was under the category of structural failure. To overcome this, it was needed to improve the subgrade soil bearing capacity. In this project, synthetic non woven geotextiles were placed at different depth of soil and the improvement in soil bearing capacity was checked by CBR and UCC test. It was observed that CBR value for the actual soil sample was very less which required nearly $75 \mathrm{~cm}$ thick pavement. But when geotextiles were introduces at various depths of soil sample, the CBR valur was increased considerably. UCC test also gave better stress values on applying geotextiles. [29]

\section{APPLICATION OF GEOSYNTHETICS IN FOUNDATION ENGINEERING}

An attempt to improve load carrying capacity and settlement characteristics of sand subgrades with horizontal reinforcement under footing foundation has been reported by Akinmusuru and Akinbolade, Binquet and Lee, Milovic and others. However, the greatest disadvantage with horizontal reinforcement is that it cannot be used in insitu condition.

Verma and Char (1986) conducted model test on strip footing of $100 \mathrm{~mm}$ width placed on sand bed reinforced by pushing iron rods vertically. It has been found that for given spacing of reinforcement the bearing capacity of footing is s function of diameter and roughness of reinforcement where as for a given type of reinforcement, the bearing capacity increases with increase in density of reinforcement.[33]

Dimbloki and Alenowicz (1988) studied the influence of geotextile on bearing cap;acity of two layer subsoil consisting of layer of sand on the surface of stiff clay. A series of plain strain footing models of $50 \mathrm{~cm}$ width and $265 \mathrm{~cm}$ length have been loaded by screw jack. The thickness of sand was varied to understanding the effect of fabric was significant at large displacement of the footing but it was nearly negligible at small deformation of full system. These was attributed to a probable reason of low initial stiffness of geotextile. Laboratory load test was conducted by loading strip footing $14.5 \mathrm{~cm}$ wide which was placed on the surface of sand beds. The angle of shearing resistance of sand is 44.50 . When deposited at a relative density of $60.5 \%$. The angle of interfaces friction between sand and geotextile is less than 1.3 times the width of footing, the geotextile would act as rigid boundary and the performance of sand bed would be deteriorated. [4]

Purkayastha and Bhaumik (1988) developed an experimental euation for B. C. of foundation on reinforced clayey slit. Model footings of size $10 \mathrm{~cm} \times 10 \mathrm{~cm}$ and $10 \mathrm{~cm} \times 12.5 \mathrm{~cm}$ were used in the investigation with geotextile layer at different depths. It was observed improvement in bearing capacity by use of geotextile reinforcement is more than that of in case of geogrids. The optimum depth for maximum improvement in bearing capacity in case of geotextile and geogrid is 0.35 times the width of footing. At this optimum depth, the improvement in bearing capacity is $46 \%$ in case of geogrids and $63 \%$ in case of geotextile reinforcement.

A notable work on annular footing testing on geotextile reinforced sand has been done by Haroon, Shah and Pandey (1990). Model footing of $100 \mathrm{~mm}$ outer diameter and having annularity ratio of $0.35,0.5$ and 0.7 were used. A woven geotextile has been used as a reinforcing material. It was observed that increase in bearing capacity due to reinforcement is about $150 \%$. [17] 
Bhide (1990) used geotextile in pile construction as an alternative to steel liner to ensure integrity of pile system. No other date regarding improvement of load bearing capacity and settlement of pile has been presented by the author. [1]

Sreekantiah (1990) reported results of the investigation of the study of behavior of geotextile reinforced sand in improving the bearing capacity and reducing settlement under square footing size $60 \mathrm{~cm} \times 60 \mathrm{~cm}$. Number of load tests were conducted to study the pressure settlement relationship for different combinations of parameters like depth of first layer of reinforcement, vertical spacing of reinforcing layers, number of layers and size of geotextile sheet. It was noticed that the ultimate bearing capacity of sand could be improved up to three times and total settlement could be reduced upto $75 \%$ by providing geotextile as reinforcing material. Size of geotextile has found to be influencing substantially the bearing capacity of sand. [30]

Sridharan, Shrinivasa, Murthy and Singh (1988) conducted model test on different sizes of footing and on circular footing. The subgrade use was form compacted sand. The reinforcement was placed in three layer. These layers were placed at a distance of 0.25 times the width of the footing. It was concluded that the shape of foundation does not affect the behavior of reinforced sand where as the size of footing has similar effect on reinforced sand as in case of unreinforced condition. [31]

Saride Sireesh carried out the study of settlement prediction geocell reinforced clay foundation. He estimated the settlements of a foundation resting on geocell reinforced clay beds using artificial neural network (ANNs). He conducted laboratory experiments to develop the model on geocell reinforced clay beds with varying geometry of geocell mattress. The analysis of test result show that the variable such as the bearing pressure of the bed with/without reinforcement, depth of placement of geocell mattress from the bed surface, width of geocell mattress, height of geocell mattress, friction ratio and coefficient of clay have a significant influence on the footing settlement. A huge database created from the experimental study was divided into three sets to train, test and validate the ANN model. The analysis of result concluded that the ANN model has very well predicted the behavior of geocell reinforced foundation beds. [24]

\section{CONCLUDING REMARKS}

Use of geotextiles have been found very effective solution in various geotechnical problem like foundation on soft soils, land slide control, pavement sub grade stabilization in road and railway construction, reinforced embankments over soft soils, erosion control etc.

\section{REFERENCES}

[1]. Bhide S. B. (1990)," Analysis and Experienced of using geotextile in piling", IGC-90, I/section, II/artcle - 12, P.119-122.

[2]. Daigavane P. B., Dawande G. M. , Gulhane S. W. , Chaudhari N. D. "Improvement of B.C. soil using geofoam prefabricated vertical drain" " Indian Geotechnical Conference-2010, IIT Bombay, December 16-18, 2010. Vol 1, P. 519 - 520.

[3]. Das N. K. , Mandal J. N., Mandal T. "Experimental and FEM analysis of the Geotextile Geotube" Indian Geotechnical Conference-2010, IIT Bombay, December 16-18, 2010. Vol 1, P. 339 - 342.

[4]. Dembicki E. and Alenowicz J. M.; "Influence of Geotextile on Bearing Capacity of Two-layer Subsoil" First Indian Geotechnical Conference on Reinforced Soil and Geotextiles (1988), P.A-61 to A-66.

[5]. Donald and Talal Al-Refeal (1985), “ Behaviour of fabric vs. fibre reinforced soil".

[6]. Freitag R. (1986), "Soil randomly reinforced with fibres", Journal of geotechnical engineering, vol. 112, No. 8, Aug-86, P. 823 - 826.

[7]. Haroon M, Shah S. S. and Pandey S.; " A study on the Behaviour of Annular Footings Resting on Geotextile Reinforced Sand", IGC-90, I/Section II/Art-1, P. 65-68, (1990).

[8]. Ingar S. S.; "Under what circumstances, the geotextile can replace traditional methods in port and marine construction?" IGC-90, I/Section, II/Exp-1, P.53-56 (1990).

[9]. Jalota A. V. , Shrivastava R. K. and Tripathi (1988), "strength and deformation behavior of geotextile reinforced alluvial clay", IGC-88, Alahabad, Dec 1988, Vol. 1, P. 219 to 223.

[10]. Mandal J. N., Divshikar D. G. (1990), “ Suggested test methods for determining creep potential of jute geotextile", IGC-90, 1/section, 11/article-11, P. 117 to P. 118.

[11]. Murthy A.V., S. R., Deep Chandra, and Jai Bhagawan (1990), "Influence of Geotextiles on swellings /swelling pressure in soft clays", IGC-90, I-section, II- art-10, p.109 - 115

[12]. Murthu B. R., Shridharan A. , Bindumadhava and Herakal R. N. (1988) , “ Soil grid reinforcement interaction", IGC-88, Allahabad, December 88, vol. 1, P.225 - 229.

[13]. Nagaraju S. S. and Mhaiskar S. Y. (1990)," Experiments on use of geotextiles and geocomposits in paved roads", IGC-90, I/section, II/article 6, P.89-92.

[14]. Natrajan T. K., Murthy A.V.S.R. and Jai Bhagwan (1987), "Geotextile Reinforcement in Soils", IGC-87, Banglore, Dec.87, Vol.1, P. 335 to P.338. 
[15]. Parab S. R., Chodankar D. S., Shirgaunkar R. M., Fernandes M. , Parab A. B., Aldonkar S. S., Savoikar P. P. "Geotubes for Beach Erosion Control in Goa" International Journal of Earth Sciences and Engineering 1013, ISSN 0974-5904, Volume 04, No 06 SPL, October 2011, P. 1013-1016.

[16]. Patel N.M.; "Reinforcing with A Geotextile Layer And Covering Pad", First Indian Geotechnical Conferance on Reinforced Soil and Geotextiles (1988), P. B-3 to P. B-7, (1988).

[17]. Purkayastha and Bhaumik (1988), "Performance of geogrid and geotextile below foundation on soft soil", IGC-1988, Allahabad, Dec-88, Vol.I, P. 199 - 204.

[18]. Raghvendra H. B. and Krishnaswamy N.R.; " Triaxial Behavior of Soil Reinforced With Geotextile", IGC-90, I/Section, II/Art-8, P.99 to P.103.,(1990)

[19]. Rao G. V. , Kate J.M. and Katti A. R. (1990), Interface friction behavior of geogrids by pullout test", IGC-90, I / section, II/article-9, P. 105-108.

[20]. Rao G. V., Gupta K. K. and Kachhawah R. (1987), “ Triaxial behavior of geotextile reinforced sand", IGC 87, Banglore, Dec-1987, vol. 1, P. 323 - 328.

[21]. Rao and Pandey (1988)," Evaluation geotextile soil friction" , Indian Geotechnical Journal 18(1), 1988, P. 77-103.

[22]. Ramaswamy S.V., Senathipathy K. and Sathiaveni (1990) , "Laboratory studies on the use of geotextiles as filters", IGC -90, 1-section, II/ Art 2, P. 69 to 72.

[23]. Rowe R. K. and Soderman K.L. (1987),"Stabilization of Very Soft Soils Using High Strength Geosynthetics: The Role of Ginite Element Analysis", Geotextiles and Geomembranes (1987), P.53 to P.80.

[24]. Saride S, "Settlement prediction of geocell reinforced clay foundations " Indian Geotechnical Conference2010, IIT Bombay, December 16-18, 2010. Vol 1, P. $899-902$.

[25]. Saxena R. K. and Sarkar S. S (1988), “ Slope erosion protection using extended polymer geogrids", FIGS (1988).

[26]. Setty K. R., Narayana swamy and Rao S. V. Gopalkrishna (1987)," characterization of fiber reinforced lateritic soil"' IGC-87, Bangalore, Dec. 87, vol. 1, P. 329 - 332.

[27]. Shroff A. V., National Level One Week Up-gradation Programme on Geosynthetics, Anchor Institute (Textile Sector) Department of Textile Engineering, Faculty of Technology \& Engineering, The Maharaja Sayajirao University of Baroda, May 17-22, 2010.

[28]. Singh R.B. and Slavoshina (1988)," Field Characteristics of an Indian Geotextile And Its Application In Soil Reinforcement", IGC-88, Allahabad, Dec-88, Vol.1, P.195 - 198.
[29]. Sivapragasam C. , Vanitha S. , Arun V. M. and Sutharsanam S. "Study on synthetic geotextiles for road pavements" Indian Geotechnical Conference-2010, IIT Bombay, December 16-18, 2010. Vol 1, P. 255 - 258.

[30]. Sreekantiah H. R.(1990), " Loaded footing on geotextile reinforced sand bed", IGC-90, I/section, II/article-3, P. 73-77.

[31]. Sridharan A., Shrinivasa Murty and Singh Hans Raj (1988), " Shape and Size Effect of Foundations On The bearing Capacity of Reinforced Soil Beds", IGC-88, Allahabad, Dec.88, Vol-1, P.205 - 210.

[32]. Subbarao C. and Prasad J. (1987),"Triaxial test on sand reinforced with polypropylene fabric", IGC-87, Banglore, Dec.1987, vol. 1, P. 319 - 322.

[33]. Verma, B.P. and Char, A.N.R. Bearing capacity tests on reinforced sand subgrades. J. Geotech. Eng. Div., AXE 1986, 112, P. 701-706 